Canadian Studies in Population, Vol. 11 (1), 1984, pp. 29-46

\title{
THE AGING OF CANADA'S POPULATION: AN UPDATE FROM THE 1981 CENSUS
}

\author{
Herbert C. Northcott \\ Department of Sociology, University of Alberta, \\ Edmonton, Alberta, Canada
}

Résumé - En 1981, 9,7 pourcent des Canadiens étaient de 65 ans ou plus. De 1971 à 1981, toutes les provinces à l'exception de l'Alberta indiquèrent une augmentation dans la proportion des âgés de leurs populations. L'Ile du Prince Edouard qui continua à avoir le plus haut pourcentage d'âgés, est suivie de la Saskatchewan, du Manitoba, de la Colombie Britannique et de la Nouvelle Ecosse. Le pourcentage de personnes âgées de 75 ans ou plus a aussi augmenté; cependant, le pourcentage des âgés très vieux a baissé légèrement durant la décennie 1971-81. Autrement dit, le taux de croissance du group d'âges 65-74 dépassa le taux de croissance du group d'âges 75 et plus. En ce qui concerne le rapport de masculinité, il y eut une augmentation continuelle du nombre de femmes âgées par chaque homme âgé. La proportion d'hommes âgés qui sont veufs a baissé, alors que contrairement aux prévisions, le pourcentage de femmes âgées qui sont veuves n'augmenta pas. Toutefois, le nombre de veuves par veuf continua à augmenter. Les âgés en 1981 furent surreprésentés partout à l'exception des plus grands centres urbains bien que les femmes âgées (et donc des veuves âgées) fussent surreprésentées dans les plus grandes régions métropolitaines. Victoria et Vancouver continuèrent à attirer des proportions relativement élevées d'habitants plus âgés.

Abstract - In 1981, 9.7 per cent of Canadians were 65 years of age or older. From 1971 to 1981, all provinces except Alberta showed an increase in the aged proportion of their populations. Prince Edward Island continued to have the highest percentage of elderly followed by Saskatchewan, Manitoba, British Columbia and Nova Scotia. The percentage of the population that is 
75 years of age or older also increased; however, the percentage of the elderly that is "old-old" declined slightly in the 1971-81 decade. In other words, the growth rate of the 65-74 age group exceeded the growth rate of the $75+$ age category. With regards to the sex ratio, there continued to be an increase in the number of elderly females for each elderly male. The proportion of elderly males who are widowed declined, while contrary to expectations, the percentage of elderly females who are widowed did not increase. Nevertheless, the number of widows for every widower continued to increase. The aged in 1981 were overrepresented in all but the largest urban centres although elderly females (and therefore elderly widows) were overrepresented in the largest metropolitan areas. Victoria and Vancouver continued to attract relatively high proportions of older residents.

Key Words - aging, sex ratio, widowhood, rural-urban

The aging of Canada's population has become a much discussed topic in the past decade (see, for example, Auerbach and Gerber, 1976; Canada, 1982; Gutman, 1982; Marshall, 1980; Myles and Boyd, 1983; Statistics Canada, 1977:35-59; Stone and Fletcher, 1981). Issues of specific concern include:

1. the rate of population aging in Canada, that is, projections as to the relative size of the elderly population (Auerbach and Gerber, 1976:8; Havens, 1982; Statistics Canada, 1977:39);

2. the growth of the "old-old" population category (Canada, 1982:1, 6; Stone and Fletcher, 1978:24)

3. trends in the elderly sex ratio (Canada, 1982:2; Statistics Canada, 1977:35-36);

4. widowhood among the elderly (Abu-Laban, 1980:125-132; Chappell, 1982:205, 215-217; Matthews, 1980); and finally,

5. the distribution (Shulman, 1980:27-32; Statistics Canada, 1977:42-43; Stone and Fletcher, 1981: charts 31-33) and re-distribution (that is, migration) of the elderly in Canada (Auerbach and Gerber, 1976:8-15; Shulman, 1980:32-34).

This paper first of all discusses the phenomenon of population aging as it relates to the demographic transition. This examination has theoretical implications with respect to the future "winding down" of the aging process and the "ultimate" percentage of aged persons in the population. Secondly, this paper uses 1971 and 1981 census data to test 
hypotheses derived from previously observed demographic trends relating to the process of population aging.

\section{Population Aging and the Demographic Transition}

As is well known, the demographic transition involves the shift from high death and birth rates (stage 1), to low death although continued high birth rates (stage 2), and finally to low death and low birth rates (stage 3). In stage two, the population age pyramid is typically triangular, that is, the young constitute a relatively large percentage of the population while the elderly make up a relatively small percentage. As the birth rate falls, the age pyramid becomes increasingly rectangular. This means that the percentage of elderly persons in the population shows a relative increase in size. This shift in the age structure has become known as the aging of the population. It follows, therefore, that these two processes - the demographic transition and population aging - are integrally related. More specifically, the phenomenon of population aging appears late in stage 2 and early in stage 3 in the demographic transition.

In stage two, the high birth rates coupled with low death rates result in rapid population growth - the so-called population explosion. As birth rates fall and stage three of the demographic transition begins, growth rates decline and the population begins to age. Some two generations after the (assumed) stabilization of the birth rate at the replacement level, zero population growth is achieved and the aging of the population ceases, that is, the growth in the percentage of elderly in the population levels off.

These relationships between population aging and the demographic transition are illustrated in Table 1 . This model and the above discussion use assumptions that greatly simplify reality, and the illustration is given for heuristic purposes only.

\section{The Aging of Canada's Population: Hypotheses}

Canada has entered stage three in the demographic transition and will experience population aging well into the next century. While the simplified model in Table 1 shows the aging process beginning and ending within two generations, in actuality the process takes very much 
TABLE 1. AN ILLUSTRATION OF THE AGING OF THE POPULATION IN THE SHIFT FROM THE SECOND TO THE THIRD STAGE OF THE DEMOGRAPHIC TRANSITION.

\begin{tabular}{lccccc}
\hline $\begin{array}{c}\text { Demographic } \\
\begin{array}{c}\text { Transition } \\
\text { Stage }\end{array}\end{array}$ & Generation & $\begin{array}{c}\text { Number of } \\
\text { Grandparents } \\
\text { (proportion of } \\
\text { population) }\end{array}$ & $\begin{array}{c}\text { Number of } \\
\text { Parents } \\
\text { proportion of } \\
\text { population) }\end{array}$ & $\begin{array}{c}\text { Number of } \\
\text { Children } \\
\text { proportion of } \\
\text { population) }\end{array}$ & $\begin{array}{c}\text { Total } \\
\text { Population }\end{array}$ \\
\hline Stage $2^{1}$ & 1 & 0 & 2 & 4 & 6 \\
& 2 & $2(1 / 7)$ & $4(2 / 7)$ & $8(4 / 7)$ & 14 \\
Stage $3^{2}$ & 3 & $4(1 / 7)$ & $8(2 / 7)$ & $16(4 / 7)$ & 28 \\
& 4 & $8(1 / 7)$ & $16(2 / 7)$ & $32(4 / 7)$ & 56 \\
& 5 & $16(1 / 5)$ & $32(2 / 5)$ & $32(2 / 5)$ & 80 \\
& 6 & $32(1 / 3)$ & $32(1 / 3)$ & $32(1 / 3)$ & 96 \\
\hline
\end{tabular}

1 Assumptions are high birth rate (4 children per couple), low death rate (all live full natural life), and no migration. In this stage, the population is increasing rapidly and the age distribution is triangular - $4 / 7$ children, $2 / 7$ parents, and $1 / 7$ grandparents.

2 Assumptions are low birth rate ( 2 children per couple), low death rate (all live full

natural life), and no migration. In this simplification, it is assumed that the shift to a lower birth rate is sudden rather than gradual. After 2 generations, the population stops growing (i.e. zero population growth is reached) and the aging of the population levels off . The age distribution is now rectangular - $1 / 3$ children, $1 / 3$ parents, $1 / 3$ grandparents.

longer inasmuch as the gradual decline in birth rates and the lengthening of life expectancy greatly extend the aging phenomenon. In fact, aging trends have been in evidence for over a century in Canada (Myles, 1982:35; Myles and Boyd, 1983:263).

Trends in data previous to the 1981 census suggest specific hypotheses regarding the aging of Canada's population. These hypotheses are tested using 1971 and 1981 census data and are as follows:

1. Given the long established pattern of population aging, it was expected that the aging trend continued to 1981 for Canada as a whole and for each province separately.

2. With respect to the population 75 years of age and older (the old-old) a. given the aging of the population and the continued increase in the life expectancy (Statistics Canada, 1977:35, 37, 49), the per 
cent of the total population that is old-old was expected to increase, and

b. the per cent of the elderly population that is old-old was expected to increase (see Stone and Fletcher, 1978:24 for the anticipated long-term trend).

3. Given that female life expectancy has continued to grow relative to the male (Statistics Canada, 1977:37, 49; Stone and Fletcher, 1981: chart 8), the ratio of elderly females to elderly males was expected to increase (Canada, 1982:2; Statistics Canada, 1977:35-36). Myles and Boyd (1983:266) note that the changing character of international migration has also contributed to this trend in the elderly sex ratio.

4. With respect to the widowed (Canada, 1982:2-3; Matthews, 1980:145-148), given that the female life expectancy continues to gain relative to the male,

a. the percentage of elderly females who are widowed was expected to increase,

b. the percentage of elderly males who are widowed was expected to decrease,

c. the ratio of widows to widowers was expected to increase, and

d. given previous trends, there was an expectation that widows would be over-represented in large urban centres.

5. Finally, with respect to the rural-urban dimension it was hypothesized

a. that the elderly would be disproportionately concentrated in the smaller urban centres (Auerbach and Gerber, 1976:10-11; Shulman, 1980:30),

b. that the number of elderly females for each elderly male would be highest in large urban centres and lowest in rural settings (Canada, 1982:2),

c. that the rural population would not age (Statistics Canada, 1977:36), and

d. that Victoria and Vancouver would continue to have relatively high proportions of elderly (Shulman, 1980:34).

The findings with respect to the above five hypotheses are discussed below. 


\section{The Findings}

\section{Population Aging}

Canada has been aging for some time now and will continue to do so well into the twenty-first century. In 1921, 4.8 per cent of Canadians were age 65 or older. By 1971, 8.1 per cent were elderly and Canada officially became an "old" nation (Auerbach and Gerber, 1976:3, 8). The 1981 census reveals that 9.7 per cent of Canadians were 65 years of age or older (Statistics Canada, 1982).

In 1971, the proportion of elderly in the population varied from province to province. Despite these variations, Table 2 shows that except for

TABLE 2. PERCENTAGE OF POPULATION THAT IS AGE 65 AND OLDER AND SEX RATIOS FOR 1971 AND 1981, BY PROVINCE.

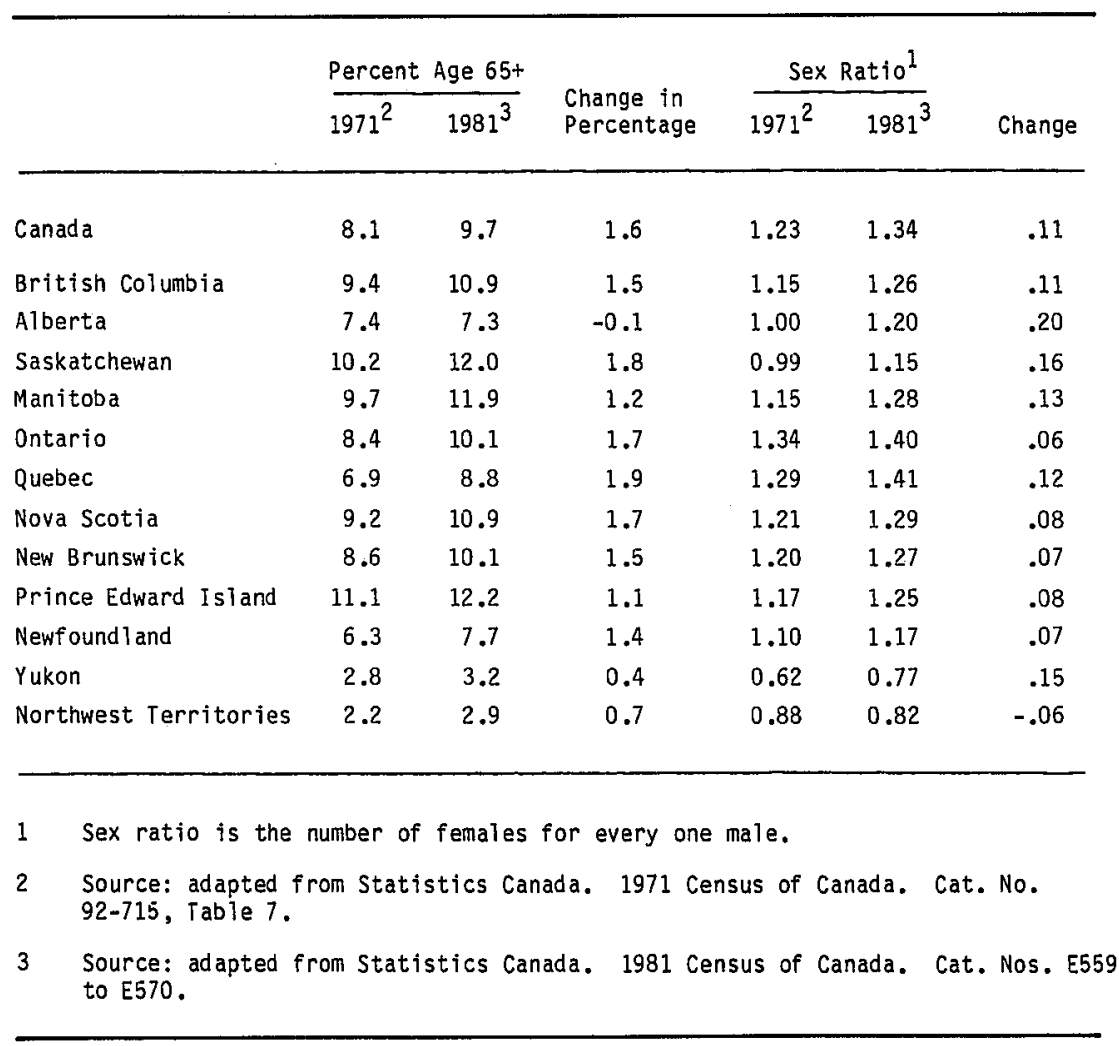


Alberta the percentage of each province's population that is elderly has increased rather substantially in the decade from 1971 to 1981 . Prince Edward Island continues to have the highest percentage of elderly followed by Saskatchewan, Manitoba, British Columbia and Nova Scotia. The ranking has remained unchanged over the decade. On the other side of the coin, the jurisdictions with the lowest percentages of elderly continue to be the Northwest Territories, the Yukon and the provinces of Newfoundland, Alberta and Québec. While in 1971 Newfoundland had the lowest provincial percentage followed by Québec and Alberta, by 1981 Alberta had the lowest provincial percentage followed by Newfoundland and Québec. Alberta was the only province to show a decline in its per cent of elderly. That province's relatively youthful population is a function of heavy in-migration during the past decade.

\section{The Old-Old}

Given that the percentage of the population 65 or more years of age is increasing, one would expect that the percentage of the population 75 or more years of age (the old-old) also would be increasing. Table 3 shows that this is indeed so. Canada as a whole, and every province except Alberta and the Yukon show increases in the per cent of the population 75 or more years of age. For Canada as a whole, the figure has risen from 3.1 per cent in 1971 to 3.6 per cent in 1981.

In addition, it was expected that the percentage of the elderly population that is old-old would increase. This anticipated increase is observed for only Québec, Ontario and the Northwest Territories. Every other province and Canada as a whole experienced a decline in the percentage of the elderly who are 75 or more years of age. Apparently the size of the $65-74$ age group is presently growing faster than the $75+$ category ( 22 per cent versus 16 per cent increase). This trend may be temporary (consider Canada, 1982:6) and should reverse as the aging process continues.

In the early stages of the aging phenomenon, the percentage of elderly who are young-old will be large. This percentage should decline in time, and the percentage of elderly who are old-old should increase. This happens as the age-sex pyramid becomes increasingly rectangular. When the aging process is complete and the elderly per cent of the population has relatively stabilized then the percentages of the elderly who are young-old and old-old should also stabilize. The ultimate relative sizes of these two elderly groups will depend on life expectancy.

Of the ten provinces, British Columbia had the largest decline in the 
TABLE 3. PERCENTAGES OF THE TOTAL AND ELDERLY POPULATIONS WHO ARE AGE 75 AND OLDER FOR 1971 AND 1981, BY PROVINCE.

\begin{tabular}{|c|c|c|c|c|c|c|}
\hline & \multicolumn{2}{|c|}{$\begin{array}{l}\text { Percent of Population } \\
\text { Who are Aged } 75+\end{array}$} & \multirow[b]{2}{*}{$\begin{array}{l}\text { Change in } \\
\text { Percentage }\end{array}$} & \multicolumn{2}{|c|}{$\begin{array}{l}\text { Percent of Elderly } \\
\text { Who are Age } 75+\end{array}$} & \multirow[b]{2}{*}{$\begin{array}{l}\text { Change in } \\
\text { Percentage }\end{array}$} \\
\hline & $1971^{2}$ & $1981^{3}$ & & 1971 & 1981 & \\
\hline Canada & 3.1 & 3.6 & .5 & 38.2 & 37.4 & -0.8 \\
\hline British Columbia & 3.9 & 4.1 & .2 & 41.9 & 37.5 & -4.4 \\
\hline Alberta & 2.9 & 2.8 & -.1 & 39.3 & 38.5 & -0.8 \\
\hline Saskatchewan & 4.4 & 4.8 & .4 & 42.9 & 39.6 & -3.3 \\
\hline Manitoba & 4.0 & 4.7 & .7 & 41.1 & 39.2 & -1.9 \\
\hline Ontario & 3.2 & 3.8 & .6 & 38.0 & 38.2 & 0.2 \\
\hline Quebec & 2.3 & 3.1 & .8 & 33.8 & 35.0 & 1.2 \\
\hline Nova Scotia & 3.8 & 4.1 & .3 & 41.0 & 37.6 & -3.4 \\
\hline New Brunswick & 3.5 & 3.9 & .4 & 40.3 & 38.1 & -2.2 \\
\hline Prince Edward Island & 4.9 & 5.1 & .2 & 44.8 & 42.0 & -2.8 \\
\hline Newfoundland & 2.3 & 2.7 & .4 & 37.7 & 34.8 & -2.9 \\
\hline Yukon & 1.0 & 0.9 &. .1 & 34.3 & 29.3 & -5.0 \\
\hline Northwest Territories & 0.6 & 1.0 & .4 & 29.6 & 32.7 & 3.1 \\
\hline
\end{tabular}

1. Elderiy is defined as age 65 and older.

2. Source: adapted from Statistics Canada. 1971 Census of Canada. Cat. No. 92-715, Table 7.

3. Source: adapted from Statistics Canada. 1981 Census of Canada. Cat. No. 92-901, Table

percentage of elderly who were 75 or older. This decline is in part a function of the relatively heavy in-migration of elderly persons of retirement age (young-old rather than old-old).

\section{The Sex Ratio}

Female life expectancy has continued to grow relative to the male, and this has meant that the ratio of elderly females to elderly males has been increasing (Statistics Canada, 1977:35-36). Table 2 shows that this trend has continued. In 1971 there were 1.23 aged females for every aged male; by 1981 the ratio was $1.34: 1$. While there are variations from province to province, every province (though not the Territories) shows an excess of elderly females relative to males. This differential has increased in all of the provinces during the 1971-81 decade. 
The Widowed

Matthews (1980:145) notes that the percentage of elderly males who are widowed appears to be declining (20.4 per cent in 1961 and 16.7 per cent in 1971) while the percentage of elderly females who are widowed appears to be increasing (48.4 per cent in 1961 and 49.4 per cent in 1971). Table 4 shows that, as expected, the elderly male in 1981 is increasingly less likely to be widowed. Contrary to expectations, however, the elderly female in 1981 did not show an increased risk of being widowed. Inasmuch as one must marry in order to become widowed, a decline in the proportion of females ever marrying might explain the decline in the proportion of widows. However, the proportion ever married has increased (from 89.3 per cent of elderly females in 1971 to 90.5 per cent in 1981). Marriage rates, therefore, cannot explain the trend in widowhood.

TABLE 4. PERCENTAGE DISTRIBUTION OF THE CANADIAN POPULATION AGE 65 AND OLDER BY MARITAL STATUS AND SEX, FOR 1971 AND 1981.

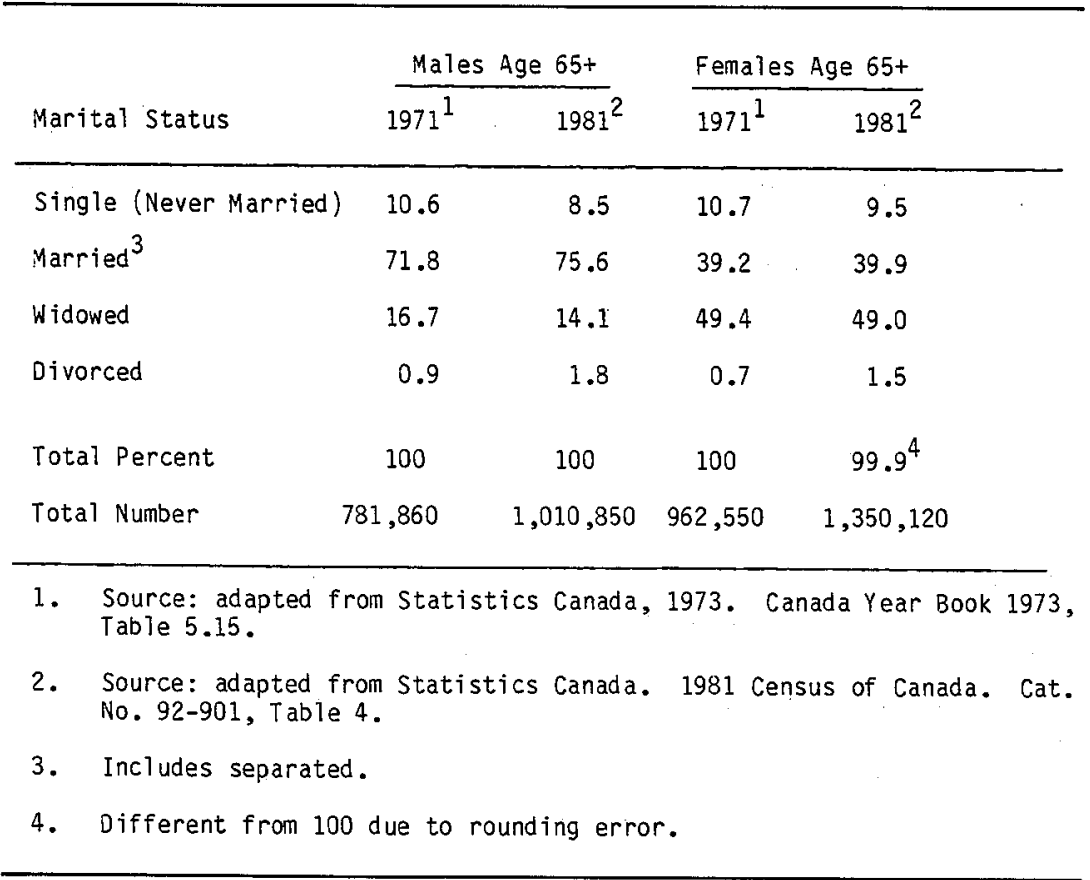


Assuming that divorced persons do not consider themselves widowed when the estranged spouse dies, the rise in the proportion divorced $(0.7$ per cent of elderly females in 1971 to 1.5 per cent in 1981) may explain, in part at least, the levelling in the rate of elderly female widowhood.

Matthews (1980:145) also notes that the ratio of widows to widowers was increasing. In 1961 there were 2.53 widows for every widower, and by 1971 the ratio was $3.65: 1$. This trend continued to 1981 when the ratio reached 4.64:1. The ratio of widows to widowers will remain high because females live longer than males on the average and because the male tends to be older than his spouse.

It has been noted that widows have been somewhat overrepresented in the largest urban centres (Matthews, 1980:147). Table 5 shows that while the elderly in general were slightly underrepresented in the larger urban centres in 1971, nevertheless, the sex ratios were largest in these same urban centres in 1971. The 1981 data again show that older women are concentrated heaviest in the larger urban centres. Table 6 shows the ratio of elderly females to elderly males for each of Canada's census metropolitan areas (CMAs) in 1971 and 1981. In 1971, when Canada's sex ratio was 1.23, all but five of Canada's CMAs had a higher relative concentration of elderly women. In 1981, all but three CMAs exceeded the Canadian sex ratio of 1.34. Given the high percentage of elderly women that are widows, these data are consistent with the findings that widows continue to be overrepresented in the large urban centres. It seems that elderly widowed females may gravitate to large centres to gain access to services offered in these major cities or to be near their adult children (Matthews, 1980:147-148).

\section{Rural-Urban Distribution}

While the elderly population is distributed along the rural-urban continuum in much the same fashion as is the population in general, nevertheless, in 1971 the elderly were slightly overrepresented in small urban centres (under 10,000) and in rural non-farm areas (Auerbach and Gerber, 1976:10-11; Shulman, 1980:30). Table 5 shows that by 1981 the elderly had become somewhat overrepresented in all urban centres except the very largest (over 500,000). In rural areas, in 1981, the elderly had become underrepresented in both farm and non-farm categories. These patterns are explained by migration (Auerbach and Gerber, 1976:11). It appears that young adults tend to move to large urban centres leaving a relatively high proportion of elderly behind in the smaller centres. When 
TABLE 5. RURAL-URBAN DISTRIBUTION OF CANADA'S TOTAL AND ELDERLY POPULATIONS FOR 1971 AND 1981.

\begin{tabular}{|c|c|c|c|c|c|c|}
\hline & \multicolumn{3}{|c|}{$1971^{1}$} & \multicolumn{3}{|c|}{$1981^{2}$} \\
\hline & $\begin{array}{l}\text { Total } \\
\text { Population } \\
(\%)\end{array}$ & $\begin{array}{c}\text { Population } \\
\text { Age } 65+ \\
(\%)\end{array}$ & $\operatorname{Sex}_{\text {Ratio }}{ }^{3}$ & $\begin{array}{c}\text { Total } \\
\text { Population } \\
(\%)\end{array}$ & $\begin{array}{l}\text { Population } \\
\text { Age 65+ } \\
(\%)\end{array}$ & $\operatorname{Sex}_{3}^{\operatorname{Sex}_{3}}$ \\
\hline Urban ${ }^{4}$ & 76.1 & 75.7 & 1.37 & 75.7 & 78.1 & 1.47 \\
\hline $500,000+$ & 31.9 & 31.1 & 1.46 & 41.2 & 39.8 & 1.53 \\
\hline $100,000-499,999$ & 15.6 & 15.0 & 1.36 & 10.5 & 11.1 & 1.48 \\
\hline $30,000-99,999$ & 9.0 & 8.7 & 1.38 & 8.2 & 8.9 & 1.43 \\
\hline $10,000-29,999$ & 8.1 & 7.8 & 1.30 & 6.4 & 6.6 & 1.39 \\
\hline $5,000-9,999$ & 3.9 & 4.0 & 1.25 & 3.3 & 3.7 & 1.37 \\
\hline $2,500-\quad 4,999$ & 3.7 & 4.5 & 1.22 & 3.3 & 4.2 & 1.36 \\
\hline $1,000-2,499$ & 3.7 & 4.6 & 1.15 & 2.8 & 4.0 & 1.28 \\
\hline Rura ${ }^{4}$ & 23.9 & 24.3 & 0.89 & 24.3 & 21.9 & 0.96 \\
\hline Non-farm & 17.3 & 29.6 & 0.94 & 20.0 & 19.6 & 1.00 \\
\hline Farm & 6.6 & 4.7 & 0.71 & 4.3 & 2.4 & 0.68 \\
\hline A11 Canada ${ }^{4}$ & 100 & 100 & 1.23 & 100 & 100 & 1.34 \\
\hline $\begin{array}{l}\text { Tota } 1 \\
\text { Number }\end{array}$ & $21,568,310$ & $1,744,410$ & & $24,343,185$ & $2,360,980$ & \\
\hline
\end{tabular}
1. Source: adapted from Statistics Canada. 1971 Census of Canada. Cat. No.
92-715, Table 8.

2. Source: adapted from Statistics Canada. 1981 Census of Canada. Cat. No. 92-901, Table 6 .

3. Sex ratio is the number of elderly females for every one elderly male.

4. Totals may not add exactly due to rounding error.

the elderly move, it appears that they tend to go from rural areas or small urban settings to somewhat larger service centres. In addition, there may be a tendency for elderly persons to return to their home towns to retire (Shulman, 1980:32). 
TABLE 6. PERCENTAGE OF POPULATION THAT IS AGE 65 AND OLDER AND SEX RATIOS, FOR 1971 AND 1981, BY CENSUS METROPOLITAN AREAS ${ }^{1}$.

\begin{tabular}{|c|c|c|c|c|c|c|}
\hline & \multirow{2}{*}{$\begin{array}{c}1981 \\
\text { Population } \\
\text { (thousands) }\end{array}$} & \multicolumn{2}{|c|}{ Percent Age $65+$} & \multirow{2}{*}{$\begin{array}{l}\text { Change in } \\
\text { Percentage }\end{array}$} & \multicolumn{2}{|c|}{ Sex Ratio ${ }^{2}$} \\
\hline & & $1971^{3}$ & $1981^{4}$ & & $1971^{3}$ & $1981^{4}$ \\
\hline Toronto & 2,999 & 7.5 & 9.1 & 1.6 & 1.52 & 1.53 \\
\hline Montrea 1 & 2,828 & 7.0 & 9.2 & 2.2 & 1.46 & 1.57 \\
\hline Vancouver & 1,268 & 10.0 & 11.5 & 1.5 & 1.26 & 1.40 \\
\hline Ottawa -Hull & 718 & 6.4 & 8.1 & 1.7 & 1.65 & 1.63 \\
\hline Edmonton & 657 & 6.0 & 6.6 & 0.6 & 1.16 & 1.35 \\
\hline Calgary & 593 & 5.7 & 6.1 & 0.4 & 1.00 & 1.46 \\
\hline Winnipeg & 585 & 9.5 & 11.5 & 2.0 & 1.33 & 1.47 \\
\hline Quebec & 576 & 6.5 & 8.3 & 1.8 & 1.57 & 1.69 \\
\hline Hamilton & 542 & 8.2 & 10.2 & 2.0 & 1.42 & 1.43 \\
\hline St. Catherines-Niagara & 304 & 8.7 & 11.5 & 2.8 & 1.30 & 1.36 \\
\hline Kitchener & 288 & 7.4 & 8.9 & 1.5 & 1.45 & 1.48 \\
\hline London & 284 & 8.7 & 10.1 & 1.4 & 1.50 & 1.51 \\
\hline Halifax & 278 & 6.4 & 7.9 & 1.5 & 1.48 & 1.48 \\
\hline Windsor & 246 & 9.4 & 11.0 & 1.6 & 1.28 & 1.46 \\
\hline Victoria & 233 & 15.1 & 17.0 & 1.9 & 1.39 & 1.51 \\
\hline Regina & 164 & 8.2 & 9.2 & 1.0 & 1.24 & 1.46 \\
\hline St. John's & 155 & 6.6 & 8.1 & 1.5 & 1.43 & 1.50 \\
\hline Oshawa ${ }^{5}$ & 154 & $n / a$ & 7.5 & $n / a$ & $n / a$ & 1.49 \\
\hline Saskatoon & 154 & 9.0 & 9.5 & 0.5 & $1: 23$ & 1.45 \\
\hline Sudbury & 150 & 4.0 & 7.1 & 3.1 & 1.09 & 1.18 \\
\hline Chicoutimi-Jonquiere & 135 & 4.2 & 6.0 & 1.8 & 1.10 & 1.27 \\
\hline Thunder Bay & 121 & 9.0 & 10.6 & 1.6 & 0.99 & 1.21 \\
\hline St. John & 114 & 9.4 & 10.4 & 1.0 & 1.46 & 1.57 \\
\hline Trois-Riveres ${ }^{5}$ & 111 & $n / a$ & 9.1 & $n / a$ & $n / a$ & 1.60 \\
\hline A11 Canada & 24,343 & 8.1 & 9.7 & 1.6 & $\begin{array}{r}1.23 \\
\end{array}$ & 1.34 \\
\hline
\end{tabular}

1. Refers to the main labour market of an urbanized area of 100,000 or more population.

2. Sex ratio is the number of elderiy females for every one elderly male.

3. Source: adapted from Statistics Canada. 1971 Census of Canada. Cat. No. 92-715, Table 11.

4. Source: adapted from Statistics Canada. 1981 Census of Canada. Cat. No. 95-903, Table 1.

5. Oshawa and Trois-Rivieres were not classified as CMAs in 1971. 
With respect to the sex ratio, it has been observed that the number of elderly females for each elderly male in 1971 was greatest in the largest urban centres and declined until elderly males outnumbered elderly females in the rural settings (Canada, 1982:2). The 1981 data contained in Table 5 continue to show this pattern.

There are three likely explanations for this rural-urban differential in the elderly sex ratio. First, because the husband tends to die before his wife, the elderly female is more likely left a widow, and it appears that the elderly widow is likely to leave rural and small urban settings to move to somewhat larger centres. Second, the elderly widower is more likely to remain on the farm than is the elderly widow. Third, the rural male is almost twice as likely as the rural female to have never married. (In 1981, 10.6 per cent of elderly rural males had never married in contrast to 5.9 per cent of elderly rural females. In urban centres, the situation is reversed, with urban elderly females being more likely to have remained single than elderly urban males.) It appears that rural farm males who have not married have had an incentive to remain on the farm, that is, they have had the family farm to work on and to inherit. On the other hand, rural females who have not married have had little incentive to remain, and the data suggest that they have moved to urban centres. In summary, the rural farm has a disproportionate concentration of elderly bachelors. This pattern is explained by the unmarried female's tendency to leave the farm and move to an urban centre.

With respect to the aging of the rural population, Statistics Canada (1977:36), interpreting 1961 and 1971 data, observed that the rural population was not aging. From 1971 to 1981, the rural non-farm population aged ( 9.1 per cent elderly in 1971 to 9.5 per cent in 1981) while the rural farm population became less aged (5.8 per cent to 5.4 per cent). This trend presumably is a function of the farm elderly, especially widows, retiring to town or city. The relatively high proportion of elderly in small urban centres supports this interpretation.

Finally, the larger cities contain the majority of Canada's elderly. In 1971,55 per cent of the population and 52 per cent of the elderly lived in Canada's 22 census metropolitan areas. In 1981, there were 24 CMAs containing 56 per cent of Canadians and 54 per cent of the elderly. As observed previously, the elderly are slightly underrepresented in these large urban centres. There are, however, considerable differences among the CMAs.

Table 6 shows that the centres with the highest percentages of elderly 
in 1971 were Victoria (15.1 per cent), Vancouver (10 per cent) and Winnipeg (9.5 per cent). In 1981, Victoria had still by far the highest concentration of elderly (17 per cent), followed by Vancouver, Winnipeg and St. Catharines-Niagara (all at 11.5 per cent). While Winnipeg's high concentration of elderly is for the most part explained by out-migration of young adults, Vancouver's and Victoria's high percentages are explained by in-migration of elderly persons seeking a warmer climate in which to retire (Shulman, 1980:32-34). Finally, note that despite the variations among the cities, the percentage of elderly in each CMA increased from 1971 to 1981 .

\section{Discussion and Summary}

The aging of Canada's population is a temporary phenomenon associated with the demographic transition, that is, declining birth and death rates. Canada now has birth rates at about the replacement level. Even if birth rates remain stable at this point, the population will continue to age over the next several generations. Furthermore, the baby boom will not begin to become old until 2012, and this will accentuate the aging of the population in the early twenty-first century. Assuming replacement level birth rates and no migration, the aging of the population will level off sometime in the next century. Of course, further declines in the birth rate and/or medical breakthroughs which substantially increase life expectancy will influence the course of population aging and the ultimate percentage of aged in the society. International migration patterns will also have an influence. For example, heavy inmigration of young persons will offset population aging. Similarly, heavy elderly out-migration (for example, to Florida) would also offset the aging of the population.

Migration internal to Canada affects the relative concentration of the elderly in the various provinces and territories and in rural versus urban settings. Out-migration of the young leaves the less mobile elderly behind in a relatively large concentration. Return migration of the elderly may add to the disproportionate size of the elderly population in smaller urban centres. The in-migration of the elderly - especially of elderly retirees - adds to the elderly populations of cities like Victoria and Vancouver where climate is a major attraction. The in-migration of elderly females (mostly widows) to the larger urban centres contributes to the excess of elderly females over elderly males in these cities. Regional dif- 
ferences in the per cent aged, then, are a function of migration patterns as well as regional differences in birth rate and life expectancy.

From 1971 to 1981, the per cent of Canada's population that is over 64 years of age increased from 8.1 to 9.7 per cent. The percentage of the population that is over 74 years of age also increased from 1971 to 1981 , although not as fast as the percentage of the population that is $65-74$ years of age. This means that the percentage of the elderly who are oldold declined somewhat. In the long run, with increases in life expectancy and with the maturing of the aging process itself, it is expected that the old-old will increase as a percentage of the elderly. The ultimate per cent of the elderly who are old-old will be a function of life expectancy, birth rates, migration patterns, and time - time will see Canada through its demographic transition and will eventually see a levelling of the process of population aging. Note that a heavy stream of elderly retirees (youngold) of varied origins but with selective destinations (for example, the West Coast) will decrease the size of the old-old population relative to the young-old in the points of destination. At the same time, the points of origin will see a relative increase in the per cent old-old.

The sex ratios show more elderly females than elderly males everywhere except in rural farm settings. The sex ratio will remain disproportionately female as long as females outlive males. Furthermore, the differential will increase as long as the gap between male and female life expectancy continues to increase.

Because of life expectancy differentials and because males tend to be older than their wives, widows greatly outnumber widowers, and this discrepancy will continue to increase. From 1971 to 1981 the percentage of elderly males who are widowed declined as expected. However, contrary to expectations, the percentage of elderly females who are widowed did not increase.

With respect to the rural-urban distribution of the elderly, the elderly are underrepresented in rural areas and overrepresented in all categories except for the largest cities. This pattern is a function of several factors: the migration of the young to the larger cities, the migration of the elderly from rural settings to nearby service centres, the return migration of the elderly and finally elderly migration motivated by a search for a low cost of living and/or escape from large city living. Furthermore, the elderly, especially males, tend to remain in the rural and smaller urban settings. In contrast, there is evidence that elderly widows tend to move to larger centres drawn by amenities, adult children and so on. Rural 
areas are more likely to have elderly bachelors than elderly spinsters. Rural males who never marry tend to stay on the farm where they can make a living; rural females who never marry tend to leave and go to cities where they can more easily make a life for themselves. This pattern has contributed to the excess of elderly females over males in urban areas and to the excess of elderly males over females on the farm. Nevertheless, the percentage of the farm population that is elderly is much lower than the Canadian average and actually declined from 1971 to 1981 . The rural farm population is not aging in contrast to rural non-farm and urban settings, both of which are aging.

Finally, while retirement migration has various motivations, one significant attraction is climate. For this reason, Victoria and Vancouver have very high concentrations of elderly persons.

In summary, Canada's population is aging and because females are living longer than males, the elderly population is increasingly disproportionately female. Further, the excess of elderly widows to elderly widowers is increasing. As Canada's elderly population grows, the needs of the aged in general and of the elderly widow in particular must be recognized and met. The uneven distribution of the elderly makes this challenge even more pressing in those areas where the aged constitute a relatively high proportion of the population. The distribution of the elderly in Canada depends significantly on the migration patterns of both the young and the old. Higher than average concentrations of aged persons result from either out-migration of the young or in-migration of the elderly. The migration of Canada's elderly population has not been studied in any detail. To fill this gap, some issues in the migration of the elderly will be addressed in separate papers.

\section{Acknowledgments}

This paper was supported in part by a leave fellowship from the Social Sciences and Humanities Research Council of Canada. Comments from anonymous reviewers have been helpful. 


\section{References}

Abu-Laban, S.M. 1980. The Family Life of Older Canadians. In V.W. Marshall (ed.), Aging in Canada. Don Mills, Ontario: Fitzhenry and Whiteside.

Auerbach, L. and A. Gerber. 1976. Implications of the Changing Age Structure of the Canadian Population. Ottawa, Ontario: Supply and Services Canada.

Canada. 1982. Canadian Governmental Report on Aging. Ottawa, Ontario: Supply and Services Canada.

Chappell, N.L. 1982. The Future Impact of the Changing Status of Women. In G.M. Gutman (ed.), Canada's Changing Age Structure. Burnaby, B.C.: Simon Fraser University Publications.

Gutman, G.M. (ed.). 1982. Canada's Changing Age Structure: Implications for the Future. Burnaby, B.C.: Simon Fraser University Publications.

Havens, B. 1982. Population Projections: Certainties and Uncertainties. In G.M. Gutman (ed.), Canada's Changing Age Structure. Burnaby, B.C.: Simon Fraser University Publications.

Marshall, V.W. (ed.). 1980. Aging in Canada. Don Mills, Ontario: Fitzhenry and Whiteside.

Matthews, A.M. 1980. Women and Widowhood. In V.W. Marshall (ed.), Aging in Canada. Don Mills, Ontario: Fitzhenry and Whiteside.

Myles, J.F. 1982. Social Implications of Canada's Changing Age Structure. In G.M. Gutman (ed.), Canada's Changing Age Structure. Burnaby, B.C.: Simon Fraser University Publications.

and M. Boyd. 1983. Population Aging and the Elderly. In D. Forcese and S. Richer (eds.), Social Issues: Sociological Views of Canada, 2nd edition. Scarborough, Ontario: Prentice-Hall.

Shulman, N. 1980. The Aging of Urban Canada. In V.W. Marshall (ed.), Aging in Canada. Don Mills, Ontario: Fitzhenry and Whiteside.

Statistics Canada. 1977. Perspective Canada II. Ottawa, Ontario: Supply and Services Canada, pp. 35-59.

1982. Canada Update from the 1981 Census. Population Trends 1981 Census. Ottawa, Ontario: Supply and Services Canada.

Stone, L.O. and S. Fletcher. 1978. A Profile of Canada's Older Population. Ottawa. Background document prepared for the Economic Council of Canada. As referred to by N. Shulman, p. 27 in V.W. Marshall (ed.), Aging in Canada. Don Mills, Ontario: Fitzhenry and Whiteside.

1981. Aspects of Population Aging in Canada: A Chartbook. Ottawa, Ontario: Supply and Services Canada.

Received April, 1983; revised September, 1983. 
